\title{
Results of sanitary-veterinary examination of fish in Poland in 2010-2016
}

\author{
RENATA PYZ-ŁUKASIK, KRZYSZTOF SZKUCIK, \\ WALDEMAR PASZKIEWICZ, ŁUKASZ DROZD
}

\begin{abstract}
Department of Food Hygiene of Animal Origin, Faculty of Veterinary Medicine,
\end{abstract} University of Life Sciences in Lublin, ul. Akademicka 12, 20-950 Lublin, Poland

Pyz-Łukasik R., Szkucik K., Paszkiewicz W., Drozd Ł.

\section{Results of sanitary-veterinary examination of fish in Poland in 2010-2016}

\section{Summary}

Fish and other fishery products are subjected to the official sanitary-veterinary controls as required by Regulation (EC) No 854/2004. The aim of the study was to analyse the results of sanitary-veterinary examinations of fish in Poland in 2010-2016 conducted by the Veterinary Inspection. The results of the laboratory examination on fish were worked out based on the annual reports issued by the General Veterinary Inspectorate. The analysis of the results included the sanitary-veterinary examination of marine and farmed fish (salmonids, cyprinids and other fish species) carried out by the Veterinary Inspection. Moreover, the sanitary evaluation of samples of fish, seafood and their products on the basis of microbiological, chemical and sensory analysis results performed by the State Sanitary Inspection (PIS) were used. Throughout the analyzed period, a total of $1436109009.60 \mathrm{~kg}$ of fish were examined, in that $145711.71 \mathrm{~kg}(0.01 \%)$ were declared unfit for human consumption. The most important reasons for fish rejection proved to be parasite invasions $(\mathbf{4 5 . 9 1 \%}$ of the total amount of discarded fish), viral diseases $(41.74 \%)$, bacterial diseases $(9.71 \%)$ and the exceeded acceptable level of histamine $(2.56 \%)$ and dioxins $(0.07 \%)$. The sanitary examination of the food samples carried out by the PIS showed that the causes of rejection included the surpassed levels of food additives $(2.3-2.7 \%$ of all the discarded samples) and chemical contaminants (1.4-2.4\%) as well as abnormal microbiological and sensory tests results (0.1-1.2\%). Summing up, the amount of fish rejected during the analyzed period was low which indicates the good quality of the obtained raw material.

Keywords: fish, examination of fish, food safety

Poland's annual catch of marine and freshwater fish reached 223.1 thousand tons in 2014 and 236.5 thousand tons in 2015. When compared with the average fish harvest in the years 2006-2010 (206.4 thousand tons) the catch was larger by $8.1 \%$ in 2014 and $14.6 \%$ in 2015. In the years 2014 and 2015, marine fish accounted for $76.5 \%$ and $79.1 \%$, respectively, of the total fish catch, while freshwater fish accounted for $23.5 \%$ and $20.9 \%$, respectively (8).

According to data supplied by the Central Statistical Office of Poland (GUS), fish and seafood consumption per capita was $13.5 \mathrm{~kg}$ in 2014 and $12.5 \mathrm{~kg}$ in 2015 (9). Compared with the year 2015, in 2016, saltwater fish consumption increased by $6 \%$, whereas that of freshwater fish remained at a similar level. Among the marine and diadromous fish, the largest consumption growth occurred for sprats, blue hake, herring and tuna, with a noticeable downturn in the consumption of salmon, cod, Alaska pollock and mackerel. Moreover, 2016 marked an increase in the domestic production of carp and trout, and a clearly lower consumer interest in imported freshwater fish species, such as panga and tilapia (4).

In accordance with Regulation (EC) No 854/2004 (7), fish and other fishery products are subject to official controls. With regard to fish, the official controls include sensory evaluation, determination of the histamine level in conformity with Reg. (EC) No 2073/2005 (2), residues and impurities in compliance with Reg. (EC) No 1881/2006 (1) and food additives in accordance with Reg. (EC) No 1333/2008 (6), as well as visual inspection for parasites in conformity with Reg. (EC) No 2074/2005 (3). When in doubt about freshness, it is recommended that the level of total volatile basic nitrogen (TVB-N) and trimethylamine nitrogen (TMA-N) be determined in compliance with Reg. (EC) No 2074/2005 (3). If well-grounded indications occur during the control procedure, a microbiological study should also be performed. According to Reg. (EC) No $854 / 2004$ (7), fishery products derived from poison- 
ous fish of the families Tetraodontidae, Molidae and Diodontidae, and on the genus Canthigaster, as well as fish containing toxins, such as ciguatera, that are hazardous to the health of consumers, must not be placed on the market. The aim of the study was to analyse the results of sanitary-veterinary examinations of fish in Poland in 2010-2016 conducted by the Veterinary Inspection.

\section{Material and methods}

The results of the laboratory tests on fish were worked out on the basis of annual reports of the General Veterinary Inspectorate (5). The analysis of the results included the sanitary-veterinary examination of marine and farmed fish. The assessment of farmed fish covered species of the Salmonidae and Cyprinidae families, as well as other unnamed fish species. The evaluation of the causes of fish rejection for human consumption was based on the results of examinations for the presence of parasites, viral and bacterial diseases, as well as acceptable levels of histamine and dioxins. The analysis also encompassed the sanitary assessment of samples collected from fish, seafood and their products subjected to microbiological, chemical and organoleptic tests by the State Sanitary Inspection (PIS) (9).

\section{Results and discussion}

The results of the sanitary-veterinary examination of fish in Poland in 2010-2016 are presented in Table 1. A total of $1436109009.60 \mathrm{~kg}$ of fish were examined, of which $145711.71 \mathrm{~kg}(0.01 \%)$ were deemed unfit for human consumption. The detention rate for particular fish groups varied considerably. The highest was noted for the salmonid fish (138 $201.41 \mathrm{~kg})$, followed by marine fish $(3789.30 \mathrm{~kg})$ and other farmed fish $(3628.00 \mathrm{~kg})$. The lowest detention was determined for the cyprinids, only $93.00 \mathrm{~kg}$. The causes of fish rejection were unnamed parasite invasions, viral diseases, i.e. viral haemorrhagic septicaemia (VHS), spring viremia of carp (SVC) and infectious hematopoietic necrosis (IHN), as well as bacterial diseases and excessive levels of histamine and dioxins.

The overall assessment showed that parasite invasions caused the highest percentage of fish rejection

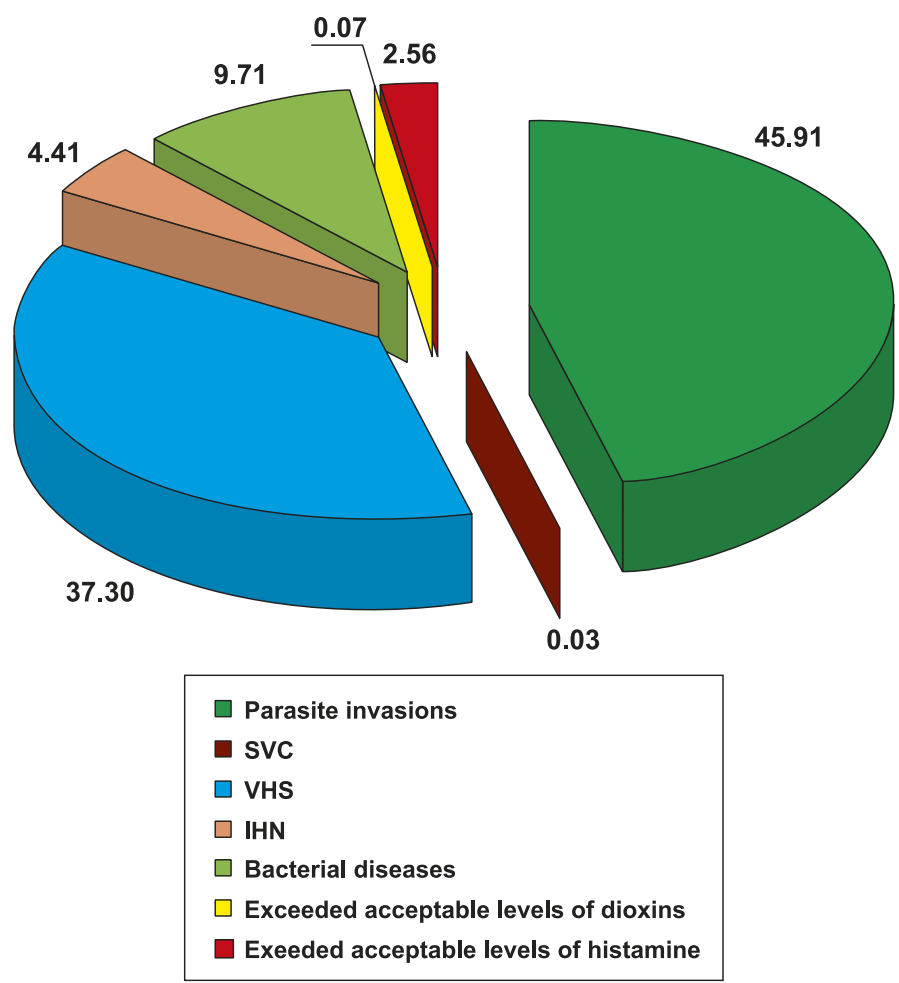

Fig. 1. Causes of fish rejection in Poland in 2010-2016

and accounted for $45.91 \%$ of the total fish declared unfit for consumption (Fig. 1). These rejections occurred at high frequency in the years 2011-2013 and caused as high as $99.99 \%$ of detentions. The parasite invasions were considered one of the primary reasons for rejection of farmed fish of the family Salmonidae (48.36\% of detentions within this family) and one of three rejection causes in the Cyprinidae family (18.29\% of detentions within it). Parasite invasions were of minor importance for rejection of marine fish and other species of farmed fish, causing $1.20 \%$ and $0.03 \%$ detentions, respectively.

The second important reason for fish rejection were viral diseases, which made up $41.74 \%$ of the total amount of rejected fish. The rejections were noted in only three reporting periods, but the viral diseases of the salmonids (VHS and IHN) were a high priority in 2014 and 2015 being responsible for $99.99 \%$ and

Tab. 1. Results of sanitary-veterinary examination of fish (in kg) in Poland in 2010-2016

\begin{tabular}{|c|c|c|c|c|c|c|c|c|c|}
\hline \multirow{3}{*}{ Year } & \multirow{3}{*}{$\begin{array}{l}\text { Total quantity } \\
\text { of fish examined }\end{array}$} & \multirow{3}{*}{$\begin{array}{l}\text { Total quantity } \\
\text { of fish declared unfit } \\
\text { (\% of examined) }\end{array}$} & \multirow{3}{*}{$\begin{array}{l}\text { Parasite } \\
\text { invasions }\end{array}$} & \multicolumn{6}{|c|}{ Causes of fish declared unfit } \\
\hline & & & & \multicolumn{3}{|c|}{ Viral disease } & \multirow{2}{*}{$\begin{array}{l}\text { Bacterial } \\
\text { disease }\end{array}$} & \multicolumn{2}{|c|}{$\begin{array}{c}\text { Exceeded acceptable } \\
\text { levels of: }\end{array}$} \\
\hline & & & & VHS & IHN & SVC & & histamine & dioxins \\
\hline 2010 & 257380716.00 & $12143.50(0.005)$ & 63.50 & 0 & 0 & 0 & 10617.00 & 1459.00 & 4.00 \\
\hline 2011 & 96580424.00 & $31322.90(0.03)$ & 31319.30 & 0 & 0 & 0 & 0 & 0 & 3.60 \\
\hline 2012 & 207336293.60 & $7740.00(0.04)$ & 7705.00 & 0 & 0 & 0 & 0 & 35.00 & 0 \\
\hline 2013 & 229957969.70 & $30188.61(0.01)$ & 27809.61 & 0 & 0 & 50.00 & 0 & 2240.00 & 89.00 \\
\hline 2014 & 229842398.00 & $53276.70(0.02)$ & 0 & 46848.00 & 6423.00 & 0 & 3.50 & 0 & 2.20 \\
\hline 2015 & 308648519.20 & $11039.00(0.04)$ & 0 & 7505.00 & 0 & 0 & 3534.00 & 0 & 0 \\
\hline 2016 & 110362689.10 & $1.00(0.0000009)$ & 0 & 0 & 0 & 0 & 0 & 0 & 1.00 \\
\hline Total & 1436109009.60 & 145711.71 & 66897.41 & 54353.00 & 6423.00 & 50.00 & 14154.50 & 3734.00 & 99.80 \\
\hline
\end{tabular}


$68 \%$ of detentions, respectively. Besides the parasite invasions, they were regarded as one of the key causes of the Salmonidae fish rejection (44\% of detentions). SVC was only reported in 2013 when it was a reason for the lowest number of detentions in both the reporting year $(0.17 \%)$ and the entire study period $(0.03 \%)$. Regarding the cyprinids, SVC contributed to more than a half $(53.76 \%)$ of all detentions.

Bacterial diseases led to $9.71 \%$ of all the detentions in the years 2010-2016. The sanitary-veterinary assessment indicated their importance in 2010 and 2015 when their percentage reached $87.43 \%$ and $32.01 \%$, respectively, in the total amount of fish declared unfit. With regard to farmed fish other than the Salmonidae and Cyprinidae, bacterial diseases constituted the first cause of detentions $(97.52 \%)$, the second in cyprinids (after SVC, 27.96\%) and the third cause in salmonids (after parasite invasions and viral diseases, 7.66\%). Bacterial diseases were not recognized in the marine fish during the analyzed period.

Analyzing the causative agents of fish rejections, the exceeded tolerable histamine level was of minor importance as it brought about $2.56 \%$ of the total fish declared unfit. It was determined in marine fish only, and contributed to $98.54 \%$ of the detentions. In 2010 and 2013, the surpassed acceptable histamine level represented the second cause of the detentions $(12.01 \%$ and $7.42 \%$ of fish regarded unfit, respectively).

Excessive concentration of dioxins was reported to occur in a low percentage $(0.07 \%$ of the total amount of fish declared unfit) and as a consequence, $2.45 \%$ of farmed fish other than salmonids and cyprinids, $0.3 \%$ of marine fish and only $0.0007 \%$ of salmonids were considered unfit.

The information concerning the quality of fishery product in Poland is complemented with the results of the official control carried out by the PIS (9). In 2010-2015, the results of the microbiological, chemical and organoleptic tests together with excessive levels of food additives led to the rejection of 1\% (2014) and 2.4\% (2011 and 2012) samples of fish, seafood and their products. The chemical examinations results including the sum total of toxic metals, residues of pesticides, mycotoxins and nitrate contamination contributed to high rates of rejection of these products, consequently, $1.4-2.4 \%$ of the samples were discarded. Whereas exceeding the permissible levels of food additives (despite the lack of data from 2010 and 2011) was the reason for rejection of $2.3-2.7 \%$ of samples. The percentage of samples discarded due to abnormal microbiological and sensory evaluation was slightly lower and ranged between $0.1 \%$ and $1.2 \%$. Listeria microorganisms were recovered from the analyzed food samples at each reporting year in $0.1-1.2 \%$ of the samples, while Salmonella rods in $0.2-0.6 \%$ in 2011, 2013 and 2015.

Summing up, the amount of rejected fish was low in the analyzed period, which is indicative of good quality of the raw material obtained. In 2016, compared to the previous years, a substantial decline in the detention numbers was noted. The detentions were a few times smaller than in 2012 and even tens of thousands lower than in 2011, 2013 and 2014. It is worth noting that, during the last three years, the microbiological factors were the predominant causes of fish rejection with the absence of parasite invasions.

\section{References}

1. Commission Regulation (EC) No 1881/2006 of 19 December 2006 setting maximum levels for certain contaminants in foodstuffs, OJ L 364 20.12.2006, p. 5.

2. Commission Regulation (EC) No 2073/2005 of 15 November 2005 on microbiological criteria for foodstuffs, OJ L 338, 22.12.2005, p.1.

3. Commission Regulation (EC) No 2074/2005 of 5 December 2005 laying down implementing measures for certain products under Regulation (EC) No 853/2004 of the European Parliament and of the Council and for the organisation of official controls under Regulation (EC) No 854/2004 of the European Parliament and of the Council and Regulation (EC) No 882/2004 of the European Parliament and of the Council, derogating from Regulation (EC) No 852/2004 of the European Parliament and of the Council and amending Regulations (EC) No 853/2004 and (EC) No 854/2004, OJ L 338 22.12.2005, p. 27.

4. Fish market, status and prospects, May 2017 IERiGŻ-PIB Warsaw.

5. General Veterinary Inspectorate: Official statistical reports from the official examination of animals and meat in 2010-2016 (RRW-6).

6. Regulation (EC) No 1333/2008 of the European Parliament and of the Council of 16 December 2008 on food additives, OJ L 354 31.12.2008, p. 16.

7. Regulation (EC) No 854/2004 of the European Parliament and of the Council of 29 April 2004 laying down specific rules for the organisation of official controls on products of animal origin intended for human consumption, OJ L 13930.4 .2004 , p. 206

8. Statistical Yearbook of the Republic of Poland, GUS, Warsaw 2016

9. Statistical Yearbooks of Agriculture, GUS, Warsaw 2010, 2011, 2012, 2013, 2014, 2015, 2016.

Corresponding author: Renata Pyz-Lukasik DVM, PhD, Akademicka 12, 20-033 Lublin, Poland; e-mail: renata.pyz@up.lublin.pl 